\title{
THE "NEW NORMAL" IN MORTGAGE LENDING AND ITS IMPACT ON DEFAULT PROBABILITIES
}

\author{
Andreas RAUTERKUS* \\ California State University San Marcos, College of Business Administration \\ Department of Finance, San Marcos, CA, USA \\ "Corresponding author's e-mail: arauterkus@csusm.edu
}

\begin{abstract}
The paper analyses the evolution of the use of subprime loans and the availability of credit to different classes of borrowers. It examines the time period from 1980 to 2008 as a whole, as well as the changes in credit profiles in five sub-periods. By tracking borrower characteristics and their impact on foreclosure probability over time it determines what went wrong and how policy can be developed that prevents a repeat of the housing crisis that began at the end of 2006. The findings suggest that over the sample period debt to income, FICO score and loan-to-value are significant determinants for the probability of foreclosure and their importance increases over time. Furthermore, some borrowers are three times more likely to default on a loan originated between 2001 and 2006 than a loan originated between 1980 and 1994 indicating a distinct difference in lending terms and the general lending environment over time.
\end{abstract}

Keywords: Foreclosure probability, residential real estate crisis, subprime mortgages.

JEL Classification: G2, G21

\section{INTRODUCTION}

In a speech at the annual meeting of the National Community Reinvestment Coalition on 14 March 2008 (federalreserve.org, 2008) the chairman of the Board of Governors of the Federal Reserve System, Ben Bernanke, outlined the severity of the mortgage crisis and the impact it had on families, neighbourhoods and the economy. He pointed out that certain market factors contributed to the crisis. In particular, he highlighted easier access to mortgage markets and lending to borrowers with imperfect credit histories. Loans made to borrowers with imperfect credit histories are commonly referred to as "subprime". The paper analyses the evolution of the use of subprime loans and the availability of credit to different classes of borrowers.

Five distinct time periods are reviewed. These time periods are formulated based, in part, on the time line established by Chomsisengphet and PenningtonCross (2006). They do not see any significant volume in the subprime market until 
about 1995 . $^{1}$ They observe the emergence of the subprime market from 1995 to 1997, followed by a temporary downturn from 1998 to 2000, with the market regaining momentum in 2001. At the end of 2006, the first problems in the subprime market are observed, so the period from 2007 to 2008 is labelled as the collapse of the subprime market. As subprime lending was prohibited before 1980, the author of the paper examines if and how credit standards have changed since 1980 and how it has affected foreclosure probabilities over time. The time period from 1980 to 2008 is examined as a whole, as well as the changes in credit profiles in the five sub-periods identified.

Numerous studies have addressed the state of the mortgage crisis and determinants of foreclosure on average. However, this paper is the first that tracks borrower characteristics and their impact on foreclosure probability over time. In that way, it tries to determine what went wrong and how policy can be developed that prevents a repeat of the housing crisis that began at the end of 2006 (this is still timely today, because current conditions in the residential real estate market could lead to a déjà vu). This study is important in that it tries to develop a guide for the choice of home ownership. Thus, the author of the paper attempts to determine if the "rules of the game" have changed and if so, what consumers need to know in order to make sound decisions in light of a "new normal". The paper is organised as follows: the next section provides a brief overview of the existing literature followed by data and methodology, findings and analysis and finally conclusions and outlook.

\section{LITERATURE REVIEW}

Chomsisengphet and Pennington-Cross (2006) examine subprime loan characteristics. Specifically, they ask "What makes a loan subprime?" The authors provide the simple explanation that the existence of a premium above the prevailing prime market rate makes a loan subprime ${ }^{2}$. In addition, they argue that the loan-tovalue ratio on subprime mortgages has to be lower than on prime mortgages to compensate the lender for the increased risk. They divide their sample according to loan type (prime, subprime and FHA) and find evidence for their hypothesis. In a related study, Pennington-Cross (2003) examines the performance characteristics of prime and subprime mortgages and finds that there are significant differences not just in terms of default probability, but also with respect to prepayment. The author finds that prime loans prepay less often than subprime loans, in particular if the credit score of the borrower improves over time. Pennington-Cross does not find evidence that elevated prepayment levels are the result of cash-out refinancing. Nichols et al. (2005) find that credit history plays an important role in the selection of mortgage type. In an earlier study, the same authors (Nichols et al., 2003) hypothesize that subprime lenders might not look at standard ratios like loan-to-

\footnotetext{
1 Straka (2000) points out that up to then lenders did not employ automated underwriting methodology and, thus, credit scores were not commonly used to make mortgage decisions.

${ }^{2}$ Later studies classify loans as subprime if they are originated by a subprime lender. The Department of Housing and Urban Development maintains a list of subprime lenders.
} 
value or price-to-income or require documentation and, thus, a subprime borrower cannot readily be defined as having little wealth or a poor credit history.

Schloemer et al. (2006) examine the trends in foreclosure and how homeowners have fared in the subprime mortgage market. Specifically, they predict subprime foreclosure rates in all major metropolitan areas of the United States and examine factors associated with subprime foreclosures. They analyse a proprietary, loanlevel database of over six million securitized subprime loans totalling $\$ 1.2$ trillion, originated from January 1998 through December 2004. They found that 1) as many as one in eight loans $(12.5 \%)$ in their sample ended in foreclosure within five years; 2) after adding the delinquent loans that were refinanced, the 'failure rate' approached $25 \%$ within five years of origination; 3 ) distressed prepayments were substitutes for foreclosure ${ }^{3}$; 4) using a modified life table, they projected that $15.4 \%$ of the loans in the sample would foreclose and that the annual predicted foreclosure rate increased throughout the sample period; and 5) one-third (33\%) of families who received a subprime loan in 2005 and 2006 would lose their homes ${ }^{4}$. The factors that they argue contribute to subprime foreclosures are loan risk, loose underwriting, predatory lending, third-party originators and inadequate oversight ${ }^{5}$.

Mallach (2007) digs deeper into the effects of the subprime industry and its impact on consumers. The author seeks to uncover the underlying issues related to how the workings of the subprime sector of the lending industry affect the public good or public welfare and how this sector should be perceived and treated by public policy. Mallach (2007) reports the effect of subprime mortgage lending on borrowers in two ways: 1) in terms of homeownership rates and the extent to which the sector leads to either increases or decreases in homeownership; and 2) in terms of the effect of subprime mortgages on the experience of homeowners and the extent to which it either does or does not impair their ability to share in the benefits of homeownership ${ }^{6}$. Citing Schloemer et al. (2006), Mallach (2007) finds that due to the associated high rate of foreclosure, the subprime mortgage sector results in an actual decline in the number of homeowners overall with that decline likely disproportionately concentrated among African-American and Latino borrowers in lower-income neighbourhoods. Mallach (2007) argues that the common features of subprime loans have the potential to negatively affect the homeownership experience in ways that affect the extent to which the borrower is likely to experience the benefits of homeownership ${ }^{7}$. Thus, the risk of foreclosures is greater

\footnotetext{
${ }^{3}$ This conclusion was drawn based on the results of a model regressing the average housing price appreciation in an MSA on the odds of a given outcome.

${ }^{4}$ This finding assumes: 1) $60 \%$ of borrowers who refinance a subprime loan will receive another subprime loan; 2) the rate of foreclosure will continue at the 2005 to 2006 rate of $19.4 \%$; and 3) these probabilities are constant for borrowers across multiple loans.

${ }^{5}$ Schloemer et al. (2006) cites loan features such as adjustable interest rates, balloon payments, prepayment penalties and low documentation requirements as those contributing to the riskiness of subprime loans.

${ }^{6}$ Mallach (2007) identifies both social and economic benefits to homeownership that can either accrue to the individual homeowner or the community. See Mallach (2007) for a list of these benefits.

${ }^{7}$ Schloemer et al. (2006) also described the common features of subprime loans as contributing to the riskiness of the loans.
} 
with subprime loans as compared with traditional loans. Mallach (2007) concludes that the existence of the subprime lending industry has resulted in a net loss of public welfare as evidenced by a net decrease in homeownership and foreclosure fears associated with the riskiness of common features embedded in subprime loans.

Gerardi et al. (2007) also consider the net effect of the subprime lending industry, but focus strictly on the state of Massachusetts. They ask: "What are the outcomes of ownership experiences in Massachusetts that started with a subprime mortgage, and what was their role in the Massachusetts foreclosure crisis of 2007?" Here, the authors differentiate between subprime loans that result from borrowers refinancing loans initially made to purchase their homes through prime lenders and home purchases initially financed with subprime loans. This exercise allows the authors to focus their analysis on the subset of subprime borrowers that some argue are not prepared for the responsibility of homeownership ${ }^{8}$. Using a dataset of deeds records from January 1987 through August 2007 for the entire state of Massachusetts and 2006 and 2007 Massachusetts assessor data, they found that approximately $30 \%$ of the 2006 and 2007 foreclosures in Massachusetts could be traced to homeowners who used a subprime mortgage to purchase their house. The authors also found that house price appreciation was the main driver of foreclosures. They estimate that the probability of default (for either a subprime or prime borrower) increases significantly in periods with low or negative house price appreciation.

Mayer and Pence (2008) examine the data sources available to examine subprime mortgages and also describe nationwide subprime lending patterns in $2005^{9}$. They found the highest concentration of subprime lending activity in Nevada, Arizona, California and Florida, where the subprime lending rates were two to three times the national average in metropolitan areas of 3.6 subprime loans per 100 housing units. Further analysis of these subprime origination trends reveals that they are only partially correlated with house price appreciation. Also, Mayer and Pence (2008) found a higher concentration of subprime lending in inner cities and the outskirts of metropolitan areas ${ }^{10}$. Lastly, they found that economically depressed areas in the Midwest do not appear to have high rates of subprime originations - despite their weak housing markets.

Anderson et al. (2008) examine the root causes of the negative outcomes related to subprime lending. They focus on changes in underwriting standards. They examine two time periods - the 1990s and post-2004 - and document specific changes in underwriting standards such as lowering of required loan-to-value ratios. Using Mortgage Bankers Association data, the authors estimate a fixed-effects model that considers the impact of both economic factors and underwriting changes on foreclosure rates. They found that both the unfavourable economic conditions and loosening of underwriting standards led to an increase in foreclosure.

\footnotetext{
${ }^{8}$ The results of the study appear to support this argument as these borrowers experience foreclosure more than six times as often as borrowers who initially finance their home through a prime lender.

${ }^{9}$ Perry (2007) also reviews data sources for subprime lending research.

${ }^{10}$ This finding is similar to that of an ICIC (2008) study discussed later, which finds a high concentration of REOs in inner cities.
} 


\section{DATA AND METHODOLOGY}

Data

To complete this study, loan-level mortgage data from LPS Applied Analytics is used. We obtain a random sample of loans outstanding as of December 2008 that represents $10 \%$ of the full LPS database. In order to determine if there is any geographical clustering of the data, we categorize the data based on the geographic region of the country where the home is located: Northeast, Midwest, South or West. Figure 1 shows that the loans are slightly concentrated in the South.

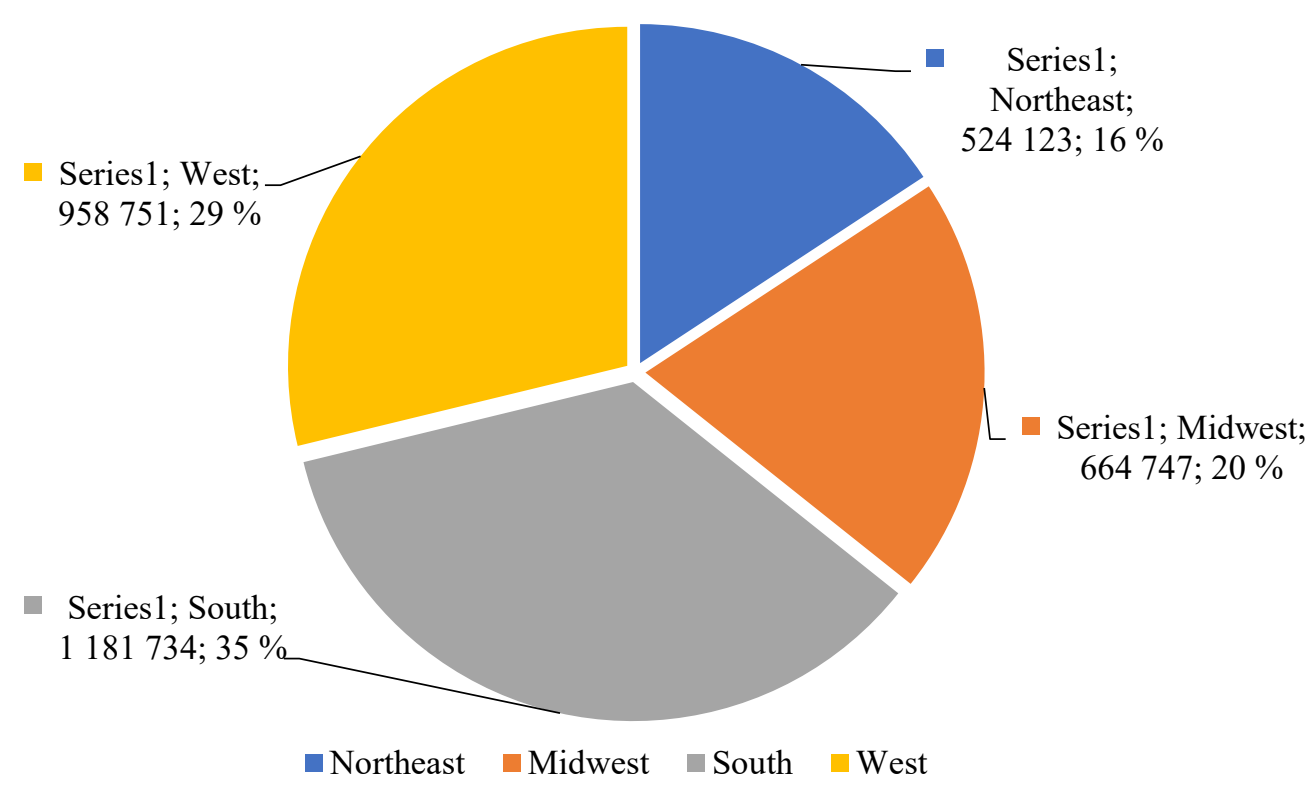

Fig. 1. Loan breakdown by geography.

The primary construct of interest is credit worthiness. Borrower credit scores at loan origination are examined to measure this construct. These scores are the output of complex proprietary models. The first such model was developed by the Fair Isaac Company in 1958 and its output is dubbed the FICO score. This is the key variable in our study. This score ranges from 350 to 850 but was not consistently used in mortgage underwriting until the mid-1990s ${ }^{11}$.

Table 1 describes the variables used in the study. Debt-to-Income is a static variable from the LPS Applied Analytics database. This measures the debt-toincome ("back end") ratio of the borrower at origination of the mortgage as reported by the servicer ${ }^{12}$. DTIs for mortgage borrowers typically range between $36 \%$ and

\footnotetext{
${ }^{11}$ See Straka (2000).

${ }^{12}$ Commonly, DTI is expressed as a pair of ratios $X / Y$ with the first ratio representing housingrelated debt and the second ratio representing all debt payments. Our dataset includes only the ratio of debt payments related to the subject loan to borrower income.
} 
$41 \%$. The sample observations have DTIs at the lower end of this range for prime loans $(35.90 \%)$ and the upper end of this range for subprime and FHA loans (39.95\% and $41.79 \%$, respectively).

FICO is also a static variable from the LPS that measures the creditworthiness of the borrower at the time of loan origination. Scores above 680 are typically considered to be very good or "prime" borrowers. In the dataset, the mean credit score is 713 . The mean credit score for prime loans is 723 and the mean credit scores for subprime and FHA loans are 620 and 648, respectively. When reviewing the data across time periods, one sees an overall decrease in credit scores over time with a trough in the 1995 to 1997 time period when average credit scores dropped to 672 across all loan types. There is a peak in the time period from 2001 to 2006 when mean credit scores reached 715 across all loan types. An additional variable is the loan-to-value ratio (LTV). LTV expresses the amount of the first mortgage lien as a percentage of the total appraised value of real property. Conforming loans, according to Fannie Mae and Freddie Mac standards, are those with LTVs less than or equal to $80 \%$. The mean LTV across all of the samples is less than $81 \%$ and is as low as $68 \%$ for subprime loans in the west. FHA loans are separated from other loans because these loans tend to have loan-to-value ratios in excess of $90 \%$. A mean loan-to-value ratio greater than $80 \%$ indicates that a significant number of the loans in the study are non-conforming loan and subject to private mortgage insurance requirements.

\section{Methodology}

The author of the study tests the null hypothesis that differences in loan default probabilities are a function of changing borrower profiles. In other words,

$\mathrm{H}_{0}$ : The change in the probability of mortgage default for a given loan type is not correlated with the change in mean credit scores for that loan type;

$\mathrm{H}_{\mathrm{A}}$ : Mortgage performance over time is related to changes in borrower profiles.

A probit regression analysis is applied to model the probability that borrowers will default on their mortgages. We use the model default $=a_{0}+b_{1}$ FICO + $b_{2} C O N T R O L+\varepsilon$, where default is a binary variable set to one if the mortgage is in default and zero otherwise; FICO is a variable measuring borrower credit worthiness and CONTROL is a vector of control variables that are widely seen as driving foreclosure risk ${ }^{13}$. These control variables include back-end debt-to-income ratio (DTI), loan-to-value ratio (LTV), loan type, and loan purpose. The author of the study estimates this model across each of the five distinct time periods that were identified as well as for the full sample. In an effort to discern possible changes in the reactions of mortgage default to the LTV, DTI, and FICO variables, interaction time period dummy variables are added to the base model. As there are five times

13 The data set consists of mortgages that have been originated since 1980 and are still active as of December 31, 2008. A mortgage is coded as in default if it is in foreclosure or REO (property that is in the hands of a lender as a result of foreclosure) in order to analyze extreme cases of default. 
periods, you run the time interaction dummy variable analysis with the base time period and each of the subsequent four time periods.

\section{FINDINGS}

Table 1 provides descriptive statistics about the sample of mortgage loans for the entire time period from 1980 to 2008 , as well as a breakdown by the previously defined sub-periods.

This table indicates that subprime loans were not a very important part of the mortgage market until 1995. In the first sub-period (1980-1994), subprime loans represent less than $0.5 \%$ of all loans originated during that period. However, the number of subprime mortgages increases in the subsequent periods reaching its highest concentration in 2001 to 2006 with over $5 \%$. Initially, the LTV on subprime loans is substantially lower than the LTV on prime loans as is hypothesized in the literature. However, over time the LTV on subprime loans increases until it surpasses the LTV ratio on prime loans. This is an evolution that is counterintuitive from a risk management perspective and seems to indicate that financial institutions lowered their lending standards over time. FICO scores seem to increase on prime borrowers over time while subprime borrowers have lower FICO, but without a decisive trend over time. Overall, the descriptive statistics seem to support the claim that an erosion in underwriting standards - particularly with regards to LTV - led to the crisis that began in the late 2006.

Table 1. Descriptive Statistics

Table 1 reports the descriptive statistics on the key quantitative variables in our sample.

\begin{tabular}{lrrrr}
\hline \multicolumn{4}{c}{ Panel A: All Loans } \\
\hline & All Loans & Prime Loans & Subprime Loans & FHA Loans \\
\hline$N$ & 3331318 & 2907615 & 134670 & 289032 \\
Appraisal amount, & 291041.20 & 307587.70 & 243605.50 & 143646 \\
$\$$ & & & & \\
Origination & 184638.70 & 190872 & 165347.50 & 130921.20 \\
amount, \$ & & & & \\
Debt-to-income, \% & 36.47 & 35.90 & 39.95 & 41.79 \\
FICO & 712.94 & 723.23 & 619.78 & 648.39 \\
Loan-to-value, \% & 81.44 & 76.56 & 72.65 & 135.45 \\
\hline & Panel C: Loans originated between 1980 and 1994 & \\
\hline$N$ & 75126 & 59541 & 351 & 15234 \\
Appraisal amount, & 133623.50 & 146186.90 & 114256.80 & 78410.14 \\
\$ & & & & \\
Origination & 829.97 & 86366.74 & 77614.76 & 68140.59 \\
amount, \$ & & & & \\
Debt-to-income, \% & 27.95 & 27.87 & 40.76 & 28.53 \\
FICO & 696.32 & 707.57 & 568.93 & 669.64 \\
Loan-to-value, \% & 92.88 & & 74.84 & 106.85 \\
\hline
\end{tabular}




\begin{tabular}{|c|c|c|c|c|}
\hline \multicolumn{5}{|c|}{ Panel D: Loans originated between 1995 and 1997} \\
\hline$N$ & 40447 & 31223 & 620 & 8604 \\
\hline $\begin{array}{l}\text { Appraisal amount, } \\
\$\end{array}$ & 121690.90 & 135075.60 & 99831.38 & 74318.07 \\
\hline $\begin{array}{l}\text { Origination } \\
\text { amount, \$ }\end{array}$ & 81011.33 & 84715.38 & 53973.70 & 69518.07 \\
\hline Debt-to-income, $\%$ & 28.06 & 28.10 & 39.91 & 27.34 \\
\hline FICO & 672.40 & 687.24 & 639.69 & 640.97 \\
\hline Loan-to-value, $\%$ & 79.96 & 76.19 & 55.89 & 95.49 \\
\hline \multicolumn{5}{|c|}{ Panel E: Loans originated between 1998 and 2000} \\
\hline$N$ & 109055 & 89535 & 2528 & 16992 \\
\hline $\begin{array}{l}\text { Appraisal amount, } \\
\$\end{array}$ & 133527.20 & 144357.50 & 94749.34 & 83157.45 \\
\hline $\begin{array}{l}\text { Origination } \\
\text { amount, } \$\end{array}$ & 92875.94 & 94467.84 & 65888.55 & 77964.44 \\
\hline Debt-to-income, $\%$ & 28.80 & 28.29 & 38.70 & 29.59 \\
\hline FICO & 691.86 & 704.61 & 593.88 & 644.72 \\
\hline Loan-to-value, \% & 78.95 & $75.00^{14}$ & 72.24 & 95.30 \\
\hline \multicolumn{5}{|c|}{ Panel F: Loans originated between 2001 and 2006} \\
\hline$N$ & 2262448 & 2033392 & 113499 & 138946 \\
\hline $\begin{array}{l}\text { Appraisal amount, } \\
\$\end{array}$ & 291169.60 & 304849.40 & 243694.30 & 125406.40 \\
\hline $\begin{array}{l}\text { Origination } \\
\text { amount, } \$\end{array}$ & 182863.80 & 188507.10 & 163828.60 & 115825.50 \\
\hline Debt-to-income, $\%$ & 36.79 & 36.13 & 39.81 & 46.71 \\
\hline FICO & 714.60 & 723.75 & 623.03 & 644.75 \\
\hline Loan-to-value, $\%$ & 81.91 & 75.91 & 72.17 & 179.53 \\
\hline \multicolumn{5}{|c|}{ Panel G: Loans originated between 2007 and 2008} \\
\hline$N$ & 820853 & 693925 & 17672 & 109256 \\
\hline $\begin{array}{l}\text { Appraisal amount, } \\
\$\end{array}$ & 331535.80 & 355856.40 & 270426.20 & 187824.50 \\
\hline $\begin{array}{l}\text { Origination } \\
\text { amount, \$ }\end{array}$ & 216214.70 & 223725.70 & 194980.60 & 171944.40 \\
\hline Debt-to-income, $\%$ & 36.52 & 36.12 & 40.78 & 38.52 \\
\hline FICO & 711.66 & 724.20 & 604.33 & 652.28 \\
\hline Loan-to-value, $\%$ & 71.84 & 68.38 & 76.30 & 92.97 \\
\hline
\end{tabular}

Table 2 summarises the results of the probit analysis on default probability.

Table 2. Probability of Default

This table shows the results of various probit models designed to estimate the probability of mortgage default given specific loan characteristics. $z$-values are in parentheses. Debt-to-income, FICO and Loan-to-value have been transformed to logged variables. Northeast, South and West are binary variables indicating the location of the home. The variable Midwest is the default variable in this sequence. Prime and Subprime are binary variables indicating the type of loan. The variable $F H A$ is the default variable in this sequence. Owner-Occupied is a binary variable indicating whether or not the home is the borrower's primary residence. Purchase, Cash-Out Refi and No-Cash Refi are binary variables indicating the purpose of the loan. Other Refi is the default variable in this sequence. $* p<0.05 ; * * p<0.01 ; * * * p<0.001$.

${ }^{14}$ The loan-to-value ratios for all loans and prime loans are medians. The mean is distorted by a large outlier in the prime loan subset. 


\begin{tabular}{|c|c|c|c|c|c|}
\hline & Model 1 & Model 2 & Model 3 & Model 4 & Model 5 \\
\hline \multicolumn{6}{|c|}{ Panel A: All Loans } \\
\hline Debt-to- & $0.1580(-$ & & & & 0.1514 \\
\hline income & $124.99) * * *$ & & & & $(31.01)^{* * *}$ \\
\hline FICO & $\begin{array}{r}-2.6108 \\
(33.73)^{* * *}\end{array}$ & & & & $\begin{array}{l}-2.1816(- \\
89.26) * * *\end{array}$ \\
\hline Loan-to- & 0.5453 & & & & 0.5655 \\
\hline value & $(66.11)^{* * *}$ & & & & $(61.79)^{* * *}$ \\
\hline Northeast & & $\begin{array}{c}-0.1791(- \\
34.49)^{* * *}\end{array}$ & & & $\begin{array}{l}-0.1417(- \\
16.37)^{* * *}\end{array}$ \\
\hline South & & $\begin{array}{r}-0.0184(- \\
4.66)^{* * *}\end{array}$ & & & $\begin{array}{r}-0.0585(- \\
8.85)^{* * *}\end{array}$ \\
\hline West & & $\begin{array}{r}-0.0097(- \\
2.35)^{* *}\end{array}$ & & & $\begin{array}{r}0.0418 \\
(6.11)^{* * *}\end{array}$ \\
\hline Prime & & & $\begin{array}{r}-0.1072(- \\
20.91)^{* * *}\end{array}$ & & $\begin{array}{r}0.3137 \\
(32.83)^{* * *}\end{array}$ \\
\hline Subprime & & & $\begin{array}{r}0.8095 \\
(124.62)^{* * *}\end{array}$ & & $\begin{array}{r}0.9800 \\
(89.92)^{* * *}\end{array}$ \\
\hline Owner- & & & & 0.0133 & $-0.2089(-$ \\
\hline Occupied & & & & $(3.26)^{* * *}$ & $28.23)^{* * *}$ \\
\hline Purchase & & & & $\begin{array}{r}0.2902 \\
(89.67)^{* * *}\end{array}$ & $\begin{array}{r}0.2558 \\
(40.82)^{* * *}\end{array}$ \\
\hline Cash-out & & & & 0.2592 & 0.1158 \\
\hline Refi & & & & $(54.76)^{* * *}$ & $(15.80)^{* * *}$ \\
\hline No-Cash & & & & $-1.2198(-$ & 0.1184 \\
\hline Refi & & & & $10.69)^{* * *}$ & $(7.32)^{* * *}$ \\
\hline Constant & $\begin{array}{r}12.1686 \\
(82.43)^{* * *}\end{array}$ & $\begin{array}{l}-1.9126(- \\
607.46)^{* * *}\end{array}$ & $\begin{array}{l}-1.9301(- \\
398.00)^{* * *}\end{array}$ & $\begin{array}{l}-2.1256(- \\
497.28) * * *\end{array}$ & $\begin{array}{r}9.0045 \\
(53.62)^{* * *}\end{array}$ \\
\hline Pseudo $R^{2}$ & 0.0845 & 0.0020 & 0.0423 & 0.0120 & 0.1243 \\
\hline$N$ & 1648237 & 3331319 & 3331319 & 3331319 & 1648237 \\
\hline \multicolumn{6}{|c|}{ Panel B: Loans originated between 1980 and 1994} \\
\hline $\begin{array}{l}\text { Debt-to- } \\
\text { income }\end{array}$ & $0.2444(0.71)$ & & & & $0.2033(0.56)$ \\
\hline FICO & $\begin{array}{r}-1.8730(- \\
2.16)^{* *}\end{array}$ & & & & $\begin{array}{r}-1.6017(- \\
1.69)^{*}\end{array}$ \\
\hline $\begin{array}{l}\text { Loan-to- } \\
\text { value }\end{array}$ & $0.9033(1.18)$ & & & & $1.7290(1.48)$ \\
\hline Northeast & & $\begin{array}{r}-0.1306(- \\
3.31)^{* * *}\end{array}$ & & & $\begin{array}{r}-0.3768(- \\
0.91)\end{array}$ \\
\hline South & & $\begin{array}{r}-0.2203(- \\
6.08) * * *\end{array}$ & & & $\begin{array}{r}-0.6109(- \\
1.60)\end{array}$ \\
\hline West & & $\begin{array}{l}-0.6143(- \\
12.35)^{* * *}\end{array}$ & & & $\begin{array}{r}-0.4297(- \\
1.20)\end{array}$ \\
\hline Prime & & & $\begin{array}{r}-0.2526(- \\
8.38) * * *\end{array}$ & & $\begin{array}{r}-0.0923(- \\
0.20)\end{array}$ \\
\hline Subprime & & & $\begin{array}{r}-0.0497(- \\
0.28)\end{array}$ & & \\
\hline Owner- & & & & 0.4008 & $-0.4537(-$ \\
\hline Occupied & & & & $(8.50)^{* * *}$ & $1.27)$ \\
\hline Purchase & & & & $0.0308(1.01)$ & $0.0231(0.05)$ \\
\hline Cash-out & & & & $-0.0010(-$ & 0.8092 \\
\hline Refi & & & & $0.01)$ & $(1.84)^{*}$ \\
\hline No-Cash & & & & $-0.1578(-$ & \\
\hline Refi & & & & $2.01)^{* *}$ & \\
\hline
\end{tabular}




\begin{tabular}{|c|c|c|c|c|c|}
\hline Constant & $5.0394(0.68)$ & $\begin{array}{c}-2.1032(- \\
73.42)^{* * *}\end{array}$ & $\begin{array}{r}-2.1407(- \\
84.57)^{* * *}\end{array}$ & $\begin{array}{l}-2.6880(- \\
55.85)^{* * *}\end{array}$ & $0.4277(0.05)$ \\
\hline Pseudo $R^{2}$ & 0.0950 & 0.0225 & 0.0080 & 0.0117 & 0.1670 \\
\hline$N$ & 1180 & 75126 & 75126 & 75126 & 1179 \\
\hline \multicolumn{6}{|c|}{ Panel C: Loans originated between 1995 and 1997} \\
\hline $\begin{array}{l}\text { Debt-to- } \\
\text { income }\end{array}$ & $0.1849(1.39)$ & & & & $0.2287(1.57)$ \\
\hline FICO & $\begin{array}{r}-0.1345(- \\
1.26)\end{array}$ & & & & $\begin{array}{r}-0.1263(- \\
1.04)\end{array}$ \\
\hline $\begin{array}{l}\text { Loan-to- } \\
\text { value }\end{array}$ & $\begin{array}{r}0.5264 \\
(2.19)^{* *}\end{array}$ & & & & $0.2938(1.01)$ \\
\hline Northeast & & $\begin{array}{r}-0.1443(- \\
3.09) * * *\end{array}$ & & & $\begin{array}{r}-0.4346(- \\
1.77)^{*}\end{array}$ \\
\hline South & & $\begin{array}{r}-0.1813(- \\
4.67)^{* * *}\end{array}$ & & & $\begin{array}{r}-0.1333(- \\
0.84)\end{array}$ \\
\hline West & & $\begin{array}{r}-0.4964(- \\
8.55)^{* * *}\end{array}$ & & & $\begin{array}{r}-0.2603(- \\
1.33)\end{array}$ \\
\hline Prime & & & $\begin{array}{r}-0.3238(- \\
9.61)^{* * *}\end{array}$ & & $\begin{array}{r}-0.3404(- \\
2.10)^{* *}\end{array}$ \\
\hline Subprime & & & $\begin{array}{r}-0.0373(- \\
0.34)\end{array}$ & & $0.4434(0.79)$ \\
\hline $\begin{array}{l}\text { Owner- } \\
\text { Occupied }\end{array}$ & & & & $\begin{array}{r}0.3266 \\
(5.12)^{* * *}\end{array}$ & $\begin{array}{r}-0.1636(- \\
0.82)\end{array}$ \\
\hline Purchase & & & & $\begin{array}{r}0.1667 \\
(4.41)^{* * *}\end{array}$ & $\begin{array}{c}0.3720 \\
(1.68)^{*}\end{array}$ \\
\hline $\begin{array}{l}\text { Cash-out } \\
\text { Refi }\end{array}$ & & & & $0.1177(0.94)$ & $\begin{array}{r}0.7009 \\
(2.75)^{* * *}\end{array}$ \\
\hline $\begin{array}{l}\text { No-Cash } \\
\text { Refi }\end{array}$ & & & & $\begin{array}{r}-0.0887(- \\
0.76)\end{array}$ & \\
\hline Constant & $\begin{array}{r}-4.3012(- \\
3.25)^{* * *}\end{array}$ & $\begin{array}{c}-1.9627(- \\
63.61)^{* * *}\end{array}$ & $\begin{array}{r}-1.9091(- \\
69.07)^{* * *}\end{array}$ & $\begin{array}{r}-2.5566(- \\
37.92)^{* * *}\end{array}$ & $\begin{array}{r}-3.2759(- \\
2.02)^{* *}\end{array}$ \\
\hline Pseudo $R^{2}$ & 0.0235 & 0.0124 & 0.0135 & 0.0086 & 0.0709 \\
\hline$N$ & 3451 & 40447 & 40447 & 40447 & 3451 \\
\hline \multicolumn{6}{|c|}{ Panel D: Loans originated between 1998 and 2000} \\
\hline $\begin{array}{l}\text { Debt-to- } \\
\text { income }\end{array}$ & $\begin{array}{r}0.1272 \\
(3.08)^{* * *}\end{array}$ & & & & $\begin{array}{r}0.0996 \\
(2.33)^{* *}\end{array}$ \\
\hline FICO & $\begin{array}{c}-2.0193(- \\
12.76)^{* * *}\end{array}$ & & & & $\begin{array}{r}-1.7203(- \\
9.56)^{* * *}\end{array}$ \\
\hline $\begin{array}{l}\text { Loan-to- } \\
\text { value }\end{array}$ & $\begin{array}{r}0.6723 \\
(6.34)^{* * *}\end{array}$ & & & & $\begin{array}{r}0.5371 \\
(4.33)^{* * *}\end{array}$ \\
\hline Northeast & & $\begin{array}{r}-0.2680(- \\
9.20)^{* * *}\end{array}$ & & & $\begin{array}{r}-0.1083(- \\
1.49)\end{array}$ \\
\hline South & & $\begin{array}{r}-0.3065(- \\
13.64)^{* * *}\end{array}$ & & & $\begin{array}{r}-0.3733(- \\
6.05)^{* * *}\end{array}$ \\
\hline West & & $\begin{array}{r}-0.5568(- \\
16.76)^{* * *}\end{array}$ & & & $\begin{array}{r}-0.3928(- \\
5.20)^{* * *}\end{array}$ \\
\hline Prime & & & $\begin{array}{r}-0.4796(- \\
22.29) * * *\end{array}$ & & $\begin{array}{r}-0.2079(- \\
3.05)^{* * *}\end{array}$ \\
\hline Subprime & & & $\begin{array}{r}0.1759 \\
(3.91)^{* * *}\end{array}$ & & $\begin{array}{r}0.3944 \\
(3.23)^{* * *}\end{array}$ \\
\hline $\begin{array}{l}\text { Owner- } \\
\text { Occunied }\end{array}$ & & & & $\begin{array}{r}0.1614 \\
(4.80) * * *\end{array}$ & $\begin{array}{r}-0.0679(- \\
076)\end{array}$ \\
\hline Purchase & & & & $\begin{array}{r}0.2251 \\
(11.05)^{* * *}\end{array}$ & $\begin{array}{r}0.1668 \\
(2.62)^{* * *}\end{array}$ \\
\hline
\end{tabular}




\begin{tabular}{|c|c|c|c|c|c|}
\hline & & & & & \\
\hline Cash-out & & & & 0.2530 & 0.2246 \\
\hline Refi & & & & $(5.07)^{* * *}$ & $(2.43)^{* *}$ \\
\hline No-Cash & & & & $-0.0493(-$ & -0.1449 \\
\hline Refi & & & & $0.75)$ & $0.52)$ \\
\hline Constant & 7.5995 & $-1.8812(-$ & $-1.7922(-$ & $-2.4148(-$ & 6.6542 \\
\hline & $(6.39) * * *$ & $111.90)^{* * *}$ & $99.67)^{* * *}$ & $69.04) * * *$ & $(4.99)^{* * *}$ \\
\hline Pseudo $R^{2}$ & 0.0809 & 0.0194 & 0.0327 & 0.0090 & 0.1179 \\
\hline$N$ & 22763 & 109055 & 109055 & 109055 & 22763 \\
\hline \multicolumn{6}{|c|}{ Panel E: Loans originated between 2001 and 2006} \\
\hline $\begin{array}{l}\text { Debt-to- } \\
\text { income }\end{array}$ & $\begin{array}{r}0.1500 \\
(28.72)^{* * *}\end{array}$ & & & & $\begin{array}{r}0.1481 \\
(26.80)^{* * *}\end{array}$ \\
\hline FICO & $\begin{array}{l}-3.0030(- \\
110.47)^{* * *}\end{array}$ & & & & $\begin{array}{r}-2.3650(- \\
71.37)^{* * *}\end{array}$ \\
\hline $\begin{array}{l}\text { Loan-to- } \\
\text { value }\end{array}$ & $\begin{array}{r}0.6805 \\
(63.49)^{* * *}\end{array}$ & & & & $\begin{array}{r}0.6456 \\
(56.47)^{* * *}\end{array}$ \\
\hline Northeast & & $\begin{array}{c}-0.1748(- \\
29.24)^{* * *}\end{array}$ & & & $\begin{array}{c}-0.1446(- \\
14.17)^{* * *}\end{array}$ \\
\hline South & & $\begin{array}{r}-0.0011(- \\
0.24)\end{array}$ & & & $\begin{array}{r}-0.0637(- \\
8.19)^{* * *}\end{array}$ \\
\hline West & & $\begin{array}{r}0.0145 \\
(3.09)^{* * *}\end{array}$ & & & $\begin{array}{r}0.0630 \\
(7.85)^{* * *}\end{array}$ \\
\hline Prime & & & $\begin{array}{c}-0.2387(- \\
37.23)^{* * *}\end{array}$ & & $\begin{array}{r}0.1900 \\
(15.38)^{* * *}\end{array}$ \\
\hline Subprime & & & $\begin{array}{r}0.6608 \\
(85.98)^{* * *}\end{array}$ & & $\begin{array}{r}0.8338 \\
(62.21)^{* * *}\end{array}$ \\
\hline Owner- & & & & 0.0162 & $-0.2156(-$ \\
\hline Occupied & & & & $(3.43)^{* * *}$ & $25.16)^{* * *}$ \\
\hline Purchase & & & & $\begin{array}{r}0.3736 \\
(100.75)^{* * *}\end{array}$ & $\begin{array}{r}0.3161 \\
(43.04)^{* * *}\end{array}$ \\
\hline Cash-out & & & & 0.3357 & 0.1867 \\
\hline Refi & & & & $(61.03)^{* * *}$ & $(21.54)^{* * *}$ \\
\hline No-Cash & & & & $-0.1303(-$ & 0.1343 \\
\hline Refi & & & & $9.23)^{* * * *}$ & $(6.27)^{* * *}$ \\
\hline Constant & $\begin{array}{r}14.2374 \\
(73.99)^{* * *}\end{array}$ & $\begin{array}{l}-1.5645(- \\
520.84)^{* * *}\end{array}$ & $\begin{array}{r}-1.75(- \\
286.81)^{* * *}\end{array}$ & $\begin{array}{c}-2.1078(- \\
424.55)^{* * *}\end{array}$ & $\begin{array}{r}9.9902 \\
(44.10)^{* * *}\end{array}$ \\
\hline Pseudo $R^{2}$ & 0.0987 & 0.0022 & 0.0463 & 0.0195 & 0.1393 \\
\hline$N$ & 1126716 & 2285838 & 2285838 & 2285838 & 1126716 \\
\hline \multicolumn{6}{|c|}{ Panel F: Loans originated between 2007 and 2008} \\
\hline Debt-to- & 0.1671 & & & & 0.1589 \\
\hline income & $(15.21)^{* * *}$ & & & & $(14.31)^{* * *}$ \\
\hline FICO & $\begin{array}{r}-2.4200(- \\
55.10)^{* * *}\end{array}$ & & & & $\begin{array}{r}-2.7450(- \\
51.91)^{* * *}\end{array}$ \\
\hline $\begin{array}{l}\text { Loan-to- } \\
\text { value }\end{array}$ & $\begin{array}{r}0.3475 \\
(26.01)^{* * *}\end{array}$ & & & & $\begin{array}{r}0.4385 \\
(28.24)^{* * *}\end{array}$ \\
\hline Northeast & & $\begin{array}{c}-0.1487(- \\
12.00)^{* * *}\end{array}$ & & & $\begin{array}{r}-0.1131(- \\
6.49)^{* * *}\end{array}$ \\
\hline South & & $\begin{array}{r}0.0281 \\
(2.96)^{* * *}\end{array}$ & & & $\begin{array}{r}-0.0176(- \\
1.31)\end{array}$ \\
\hline West & & $\begin{array}{c}0.0161 \\
(1.65)^{*}\end{array}$ & & & $\begin{array}{r}0.0474 \\
(3.39)^{* * *}\end{array}$ \\
\hline Prime & & & $\begin{array}{r}0.1876 \\
(15.94)^{* * *}\end{array}$ & & $\begin{array}{r}0.5661 \\
(31.94)^{* * *}\end{array}$ \\
\hline Subprime & & & $\begin{array}{r}1.0948 \\
(65.36)^{* * *}\end{array}$ & & $\begin{array}{r}1.0143 \\
(45.77)^{* * *}\end{array}$ \\
\hline
\end{tabular}




\begin{tabular}{|c|c|c|c|c|c|}
\hline \multicolumn{4}{|l|}{ Owner- } & -0.0155 & -0.1958 \\
\hline \multicolumn{4}{|l|}{ Occupied } & $(01.73)^{*}$ & $12.61)^{* * *}$ \\
\hline \multirow{2}{*}{\multicolumn{4}{|c|}{ Purchase }} & 0.0903 & 0.0800 \\
\hline & & & & $(11.89)^{* * *}$ & $(6.23) * * *$ \\
\hline \multicolumn{4}{|l|}{ Cash-out } & 0.0793 & -0.0559 \\
\hline \multicolumn{4}{|l|}{ Refi } & $(7.94)^{* * *}$ & $3.87)^{* * *}$ \\
\hline \multicolumn{4}{|l|}{ No-Cash } & $-0.0725(-$ & 0.0638 \\
\hline \multicolumn{4}{|l|}{ Refi } & $3.36)^{* * *}$ & $(2.49)^{* *}$ \\
\hline \multirow[t]{2}{*}{ Constant } & 11.5959 & $-2.0956(-$ & $-2.3153(-$ & $-2.1407(-$ & 13.0097 \\
\hline & $(38.20)^{* * *}$ & $268.41)^{* * *}$ & $207.28)^{* * *}$ & $232.51)^{* * *}$ & $(36.52)^{* * *}$ \\
\hline Pseudo $R^{2}$ & 0.0659 & 0.0020 & 0.0307 & 0.0013 & 0.1000 \\
\hline$N$ & 494127 & 820853 & 820853 & 820853 & 494127 \\
\hline
\end{tabular}

The first remarkable result is that a classification as a subprime mortgage does not increase default probability until 1998. This seems to indicate that during this time loans were considered subprime not due to a higher default risk, but due to other factors such as lack of documentation or problems with the borrower's credit history. This finding is supported by the very low LTV ratios prior to 1998. This seems to indicate that subprime borrowers did have the means to provide a significant down payment on their home purchase. Furthermore, in the last two periods (2001 to 2006 and 2007 to 2008) even prime loans show a positive coefficient indicating that both prime loans and subprime loans increase the probability of default. During this time, default probability increased for all loan types. This indicates that at this point mortgage quality in general deteriorated.

Table 3 summarises the results of the inter-period analysis.

Table 3. Cross-Period Results

This table reports the results of two probit models to estimate the probability of default given the change in DTI, LTV and FICO scores from period to period along with other control variables. $z$-values are in parentheses. Debt-to-income, FICO and Loan-to-value have been transformed to logged variables. Northeast, South and West are binary variables indicating the location of the home. The variable Midwest is the default variable in this sequence. Prime and Subprime are binary variables indicating the type of loan. The variable $F H A$ is the default variable in this sequence. Owner-Occupied is a binary variable indicating whether or not the home is the borrower's primary residence. Purchase, Cash-Out Refi and No-Cash Refi are binary variables indicating the purpose of the loan. Other Refi is the default variable in this sequence. ${ }^{*} p<0.05$; $* * p<0.01 ; * * * p<0.001$.

Panel A: 1980 to 1994 and 1995 to 1997

\begin{tabular}{lrr}
\hline & Model 1 & \multicolumn{1}{c}{ Model 2 } \\
\hline Debt-to-income & $0.1279(0.66)$ & $0.1465(0.70)$ \\
FICO & $-0.1397(-1.31)$ & $-0.1055(-0.86)$ \\
Loan-to-value & $0.5876(1.93)^{*}$ & $0.3281(0.94)$ \\
Debt-to-income*Later Period & $0.0035(0.52)$ & $0.0042(0.57)$ \\
FICO*Later Period & $-0.0002(-0.58)$ & $-0.0004(-0.88)$ \\
Loan-to-value*Later Period & $0.0004(0.20)$ & $0.0011(0.52)$ \\
Northeast & & $-0.3815(-1.86)^{*}$ \\
South & & $-0.1974(-1.37)$ \\
West & & $-0.3243(-1.89)^{*}$ \\
Prime & & $-0.3367(-2.25)^{* *}$ \\
Subprime & & $0.4317(0.78)$ \\
Owner-Occupied & & $-0.2342(-1.41)$
\end{tabular}


Purchase

Cash-out Refi

Constant

Pseudo $R^{2}$

N
$-4.3565(-2.99)^{* * * *}$ 0.0302
$0.3624(1.87)^{*}$ $0.7367(3.40)^{* * *}$ $-3.1687(-1.87)^{*}$ 01.0798 4630

\begin{tabular}{lr}
\hline & Panel B: 1995 to 1997 and 1998 to \\
\hline Debt-to-income & $-0.0628(-1.12)$ \\
FICO & $-0.3766(-6.02)^{* * *}$ \\
Loan-to-value & $0.6461(5.64)^{* * *}$ \\
Debt-to-income*Later Period & $0.0103(4.32)^{* * *}$ \\
FICO*Later Period & $-0.0007(-4.74)^{* * *}$ \\
Loan-to-value*Later Period & $0.0010(1.59)$
\end{tabular}

Northeast

South

West

Prime

Subprime

Owner-Occupied

Purchase

Cash-out Refi

No-Cash Refi

Constant

Pseudo $R^{2}$

$-2.2917(-3.47) * * *$

0.0498

N

26214

Panel C: 1998 to 2000 and 2001 to 2006

\begin{tabular}{|c|c|c|}
\hline Debt-to-income & $0.4944(34.67)^{* * *}$ & $0.3203(23.11)^{* * *}$ \\
\hline FICO & $-3.5484(-93.14) * * *$ & $-2.6860(-63.81) * * *$ \\
\hline Loan-to-value & $0.7010(62.70)^{* * *}$ & $0.6650(55.71)^{* * *}$ \\
\hline Debt-to-income*Later Period & $-0.0095(-26.61)^{* * *}$ & $-0.0050(-13.83)^{* * *}$ \\
\hline FICO*Later Period & $0.0009(23.15)^{* * *}$ & $0.0006(14.38)^{* * *}$ \\
\hline Loan-to-value* Later Period & $-0.0000(-1.93)^{*}$ & $-0.0000(-1.78)^{*}$ \\
\hline Northeast & & $-0.1467(-14.50)^{* * *}$ \\
\hline South & & $-0.0708(-9.18) * * *$ \\
\hline West & & $0.0505(6.32)^{* * *}$ \\
\hline Prime & & $0.1651(13.59)^{* * *}$ \\
\hline Subprime & & $0.8063(60.53)^{* * *}$ \\
\hline Owner-Occupied & & $-0.2206(-25.84)^{* * *}$ \\
\hline Purchase & & $0.3028(41.33)^{* * *}$ \\
\hline Cash-out Refi & & $0.1757(20.28)^{* * *}$ \\
\hline No-Cash Refi & & $0.1169(5.46)^{* * *}$ \\
\hline Constant & $16.2138(69.07)^{* * *}$ & $11.2373(42.84)^{* * *}$ \\
\hline Pseudo $R^{2}$ & 0.1018 & 0.1399 \\
\hline$N$ & 1149479 & 1149479 \\
\hline \multicolumn{3}{|c|}{ Panel D: 2001 to 2006 and 2007 to 2008} \\
\hline Debt-to-income & $0.1585(30.89)^{* * *}$ & $0.1610(29.82)^{* * *}$ \\
\hline FICO & $-2.9233(-122.40) * * *$ & $-2.5193(-87.61) * * *$ \\
\hline Loan-to-value & $0.6630(67.24)^{* * *}$ & $0.6194(59.96)^{* * *}$ \\
\hline Debt-to-income*Later Period & $-0.0007(-2.13)^{* *}$ & $-0.0016(-4.58)^{* * *}$ \\
\hline FICO*Later Period & $0.0004(11.04)^{* * *}$ & $0.0002(4.33) * * *$ \\
\hline Loan-to-value*Later Period & $-0.0057(-20.95) * * *$ & $-0.0028(-9.67)^{* * *}$ \\
\hline Northeast & & $-0.1392(-15.84)^{* * *}$ \\
\hline South & & $-0.0522(-7.79)^{* * *}$ \\
\hline West & & $0.0569(8.20)^{* * *}$ \\
\hline Prime & & $0.3200(31.91)^{* * *}$ \\
\hline Subprime & & $0.9231(81.91)^{* * *}$ \\
\hline
\end{tabular}




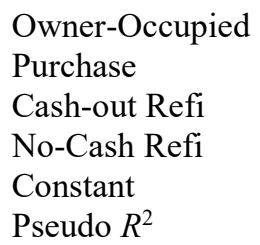

Taking a closer look at some of the sub-periods that were identified as important provides some interesting insights. In the period from 1980 to1997, debtto-income, FICO score and loan-to-value ratio were not significant predictors of mortgage default. This indicates that during this period the measures most commonly associated with mortgage default risk did not matter. As a matter of fact, most variables in the model are not significant suggesting that mortgage default during that period was caused by unpredictable events that would impair a borrower's ability to repay the loan, such as loss of job or illness. Thus, during this time residential mortgage loans could be viewed as very low risk regardless of a borrower's credit profile. This changes in the subsequent periods with debt-toincome and FICO score gaining more and more predictive power from period to period. Loan-to-value ratio becomes a significant predictor of mortgage default starting in 1998, but unlike debt-to-income and FICO its importance as a predictor does not change ${ }^{15}$.

These results coincide with a large increase in real estate prices over the same period (see Fig. 2).

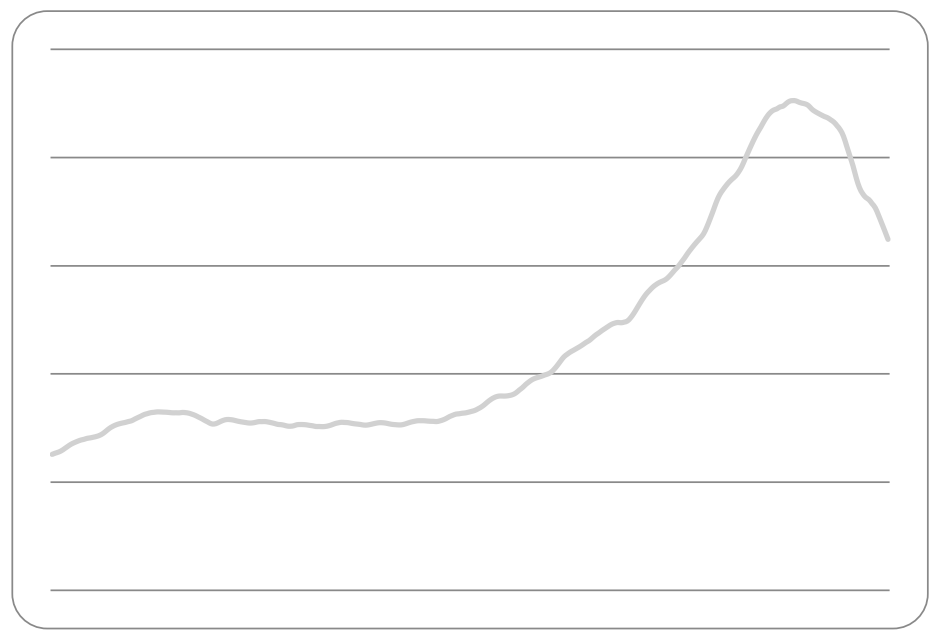

Fig. 2. S\&P/Case-Shiller Home Price Index.

This confirms the hypothesis that during the time period of 1998 to 2006 lenders did not worry about the LTV at origination because they expected a significant increase in the value of the home that would mitigate a potential initial

\footnotetext{
${ }^{15}$ While the coefficient on the time interaction variable for LTV is significant in panel B-D in Table 3 , the value of the coefficient is not economically meaningful. It is essentially zero.
} 
risk of high LTV ratios ${ }^{16}$. Overall, one can observe that the probability of mortgage default increases steadily over time for lower FICO scores and higher DTI ratios and to a lesser extent for higher LTV ratios. Thus, the probability of default of mortgage originated in 2006 is much higher than the default probability of mortgage originated in 1980 by a borrower with the same profile. Table 4 illustrates an example over different time period.

Table 4. Default Probabilities for Different Borrower Profiles over Time

This table shows the probability of default of a typical subprime, average or prime borrower dependent upon the year that the loan was originated based on the results of our model.

\begin{tabular}{|c|c|c|c|}
\hline \multirow[b]{2}{*}{$\begin{array}{c}\text { Loan Origination } \\
\text { Year }\end{array}$} & \multicolumn{3}{|c|}{ Default Probability by Borrower Type } \\
\hline & $\begin{array}{c}\text { Subprime Borrower: } \\
\text { Debt-to-income } 36 \% \\
\text { FICO score } 650 \\
\text { Loan-to-value } 81 \%\end{array}$ & $\begin{array}{c}\text { Average Borrower: } \\
\text { Debt-to-income } 36 \% \\
\text { FICO score } 713 \\
\text { Loan-to-value } 81 \%\end{array}$ & $\begin{array}{c}\text { Prime Borrower: } \\
\text { Debt-to-income } 36 \% \\
\text { FICO score } 750 \\
\text { Loan-to-value } 81 \%\end{array}$ \\
\hline 1980 & $1.23 \%$ & $0.78 \%$ & $0.60 \%$ \\
\hline 1995 & $1.40 \%$ & $1.36 \%$ & $1.33 \%$ \\
\hline 2000 & $1.96 \%$ & $1.20 \%$ & $0.91 \%$ \\
\hline 2006 & $4.60 \%$ & $2.48 \%$ & $1.72 \%$ \\
\hline 2008 & $2.54 \%$ & $1.48 \%$ & $1.10 \%$ \\
\hline
\end{tabular}

Using the average characteristics for borrower over the whole sample period, namely a $36 \%$ debt-to-income ratio, a 713 FICO score and loan-to-value ratio at origination of $81 \%$, the probability of default of this borrower increased from $0.8 \%$ in 1980 to $2.5 \%$ in 2006. Default probabilities were declining between 2007 and 2008, because lenders started to tighten their lending standards. Examining the different borrower profiles reveals that even though default probabilities are lower for higher FICO scores and higher for lower scores, the general trend is the same across all borrower profiles.

\section{DISCUSSION}

The findings support previous studies that examined the determinants of mortgage foreclosure. Over a period from 1980 to 2008 debt-to-income, FICO score and loan-to-value are significant determinants for the probability of foreclosure. However, the study goes beyond just looking at foreclosure determinants at a given point in time, but tracks them over a 29-year period. It found that the aforementioned factors played an increasing role in predicting foreclosure over the last 29 years. However, in the period from 2001 to 2006 one sees the largest growth in mortgage originations, yet the loan-to-value ratio does not seem to become a stronger predictor of mortgage default ${ }^{17}$. The average loan-to-value ratio does not increase from 1998 to 2006. This is an indicator that the amount borrowed during this time increased significantly, given the dramatic increase in house prices.

\footnotetext{
${ }^{16}$ From 1998 to 2006, the S\&P/Case-Shiller Home Price Index increased by $175 \%$

${ }^{17} 67.8 \%$ of the mortgages in the sample were originated between 2001 and 2006 .
} 
Incidentally, the average mortgage origination amount in the sample doubled between 1998 and 2006.

To get a better handle on how the mortgage market has changed, the default probability of a borrower over the sample period is calculated. Creating a generic borrower profile with a debt-to-income ratio of $36 \%$, a FICO score of 713 and a loan-to-value ratio of $81 \%$, the author of the study tried to determine how the probability of mortgage default would change for mortgages originated in different time periods. The study shows that the default probability of mortgage originated between 2001 and 2006 is more than three times higher than the default probability of mortgage originated between 1980 and 1994. Repeating the calculation for two different borrower profiles (one considered high risk with a low FICO score and one considered low risk with a high FICO score) an identical result was found. Thus, the probability of mortgage default for the whole spectrum of credit risk tripled between 1980 and 2006. However, mortgage default rates decrease for loans originated in 2007 and 2008. This can be attributed to very tight lending standards as a result of the foreclosure crisis.

Many reasons come to mind when looking for explanations for the observed development. A common explanation for the high default rates recently is the mortgage origination amount. However, looking at the results, that does not seem to be true. The paper finds an increase in default rates holding debt-to-income and loan-to-value ratios constant over time. Thus, borrowers do not finance higher proportions of the home price and they do not take on more debt payments relative to their income than they did in 1980. Thus, the reasons must lie somewhere else. One of the reasons might be the many different kinds of mortgage loans that were available then, but were not available in $1980 .{ }^{18}$ Lenders offered mortgages with adjustable interest rates, balloon payment options and interest only mortgage loans, to name just a few. Another explanation could be the decline of home values from its peak in 2006 to the levels of December $2008^{19}$. Pennington-Cross (2003) finds that the probability of default increases with a decrease in equity in the home, a result that is confirmed by this study. Thus, while loan-to-value ratios were the same at origination for the sample, loans that were originated at a loan-to-value ratio of $81 \%$ would find themselves at $100 \%$ if the value of the home decreased by $25 \%$ (as the home-price index indicates). This should not necessarily impede the borrower's ability to make the monthly payments, but has an impact on their ability to refinance or sell the home.

While the risk of default is a risk that is ultimately born by the lender and not the borrower, the results of this study have some implications for consumers (borrowers). It seems to be evident that the market for house financing in 2008 (and the same is true for today where we observe similar circumstances) is more complex than it was in 1980 and there are many more factors to consider when making a decision to purchase a home. For the first time in more than 25 years, housing prices experienced a significant decline at that time and this decline had an impact on default risk. Thus, a today's borrower not only has to be concerned with their credit

\footnotetext{
${ }^{18}$ This does not refer to subprime loans, which were available during the entire sample period.

${ }^{19}$ The S\&P/Case-Shiller Home Price Index declined by almost $26 \%$ between December 2006 and December 2008.
} 
profile, but also with the direction of the housing market. The paper finds that a borrower's credit profile is indicative of their default probability. However, the credit profile is not a static variable. Credit profiles change over time and while debt-to-income and the FICO score can be influenced by the borrower, the loan to value ratio is an external factor on which the borrower has little influence (except through early principal repayments). Yet, deteriorating loan-to-value ratios seem to have a profound impact on default probabilities. This suggests that in addition to a current loan-to-value ratio, lenders and borrowers should be concerned with a loan to future value ratio, as well.

In conclusion, the "New Normal" is a world where lenders and borrowers need to take into consideration the risk of decreasing home values. In the past, lenders under-priced this risk and borrower ignored it completely. Going forward, borrowers need to be educated about the risks of declining home values and how they could possible lead to mortgage foreclosure. Thus, policy makers and consumer groups should create awareness of this risk.

\section{REFERENCES}

Anderson, C. D., Capozza, D. R., \& Van Order, R. (2008). Deconstructing the Subprime Debacle Using New Indices of Underwriting Quality and Economic Conditions: A First Look. SSRN. https://doi.org/10.2139/ssrn.1160073

Bernanke, B. S. (2008). Fostering Sustainable Homeownership, Speech at the National Community Reinvestment Coalition Annual Meeting. www.federalreserve.gov

Chomsisengphet, S., \& Pennington-Cross, A. (2006). The Evolution of the Subprime Mortgage Market. Federal Reserve Bank of St. Louis Review, 88(1), 31-56. https://doi.org/10.20955/r.88.31-56

Gerardi, K., Shapiro, A. H., \& Willen, P. S. (2007). Subprime Outcomes: Risky Mortgages, Homeownership Experiences, and Foreclosures. FRB of Boston Working Paper No. 07-15. https://doi.org/10.2139/ssrn.1073182

Mallach, A. (2007). Lower Income Homeownership, the Subprime Lending Industry and the Public Good: A Conceptual Inquiry. Unpublished working paper.

Mayer, C., \& Pence, K. (2008). Subprime Mortgages: What, Where, and to Whom? NBER Working Paper Series No. 14083. https://doi.org/10.3386/w14083

Nichols, J., Pennington-Cross, A., \& Yezer, A. (2005). Borrower Self-Selection, Underwriting Costs, and Subprime Mortgage Credit Supply. The Journal of Real Estate Finance and Economics, 30(2), 197-219. https://doi.org/10.1007/s11146-004-4879-8

Pennington-Cross, A. (2003). Credit History and the Performance of Prime and Nonprime Mortgages. The Journal of Real Estate Finance and Economics, 27(3), 279-301. https://doi.org/10.1023/A:1025891223226

Pennington-Cross, A., Yezer, A., \& Nichols, J. (2003). Credit Risk and Mortgage Lending: Who Uses Subprime and Why? Working Paper No.00-03. Research Institute for Housing America.

Schloemer, E., Li, W., Ernst, K., \& Keest, K. (2006). Losing Ground: Foreclosures in the Subprime Market and Their Cost to Homeowners. Center for Responsible Lending.

Straka, J. W. (2000). A Shift in the Mortgage Landscape: The 1990s Move to Automated Credit Evaluations. Journal of Housing Research, 11(2), 207-232. 


\begin{abstract}
AUTHOR'S SHORT BIOGRAPHY
Andreas Rauterkus earned his $\mathrm{PhD}$ in Finance from the University of Cincinnati. He also holds an MBA from East Carolina University and an undergraduate/graduate degree in Finance and Banking from J. W. Goethe University in his native Frankfurt am Main, Germany. Dr Rauterkus spent three years as a Finance Instructor at Louisiana State University in Baton Rouge; he taught at Siena College in Loudonville, NY, at the University of Alabama at Birmingham. Currently, he is an Associate Professor of Finance Chair of the Finance Department at California State University, San Marcos. His research interests are in financial institutions and credit markets with an emphasis on conflict of interest situations in international banking. Further, Dr Rauterkus possesses comparative knowledge of international banking systems and current trends - especially with respect to the European Union countries. Most recently, Dr Rauterkus focused his research on small business lending, the impact of lender distance on loan performance and the role of credit unions. In addition, Dr Rauterkus conducts research on the effect of the foreclosure crisis on credit analysis and mortgage lending decisions. Dr Rauterkus has presented his research at conferences in the USA and Europe. His research has been published in a book and academic journals. He was awarded a research fellowship by the FDIC's Centre for Financial Studies. Dr Rauterkus has been interviewed on numerous topics concerning the economy and financial markets and institutions by regional, national and international media outlets.

E-mail: arauterkus@csusm.edu

ORCID iD: https://orcid.org/0000-0001-7076-4821
\end{abstract}

